\title{
Local Food as a Tool of Tourism Development in Regions
}

\author{
Alžbeta Királ'ová, College of Regional Development and Banking Institute - AMBIS, Czech Republic \\ https://orcid.org/0000-0002-7182-1311 \\ Lukáš Malec, University College of Business in Prague, Czech Republic
}

\begin{abstract}
This study aims to identify the importance of local food for both the demand and supply sides and to show how local food can be bounded with tourism development in the region. The data presented are based on secondary and primary research. Secondary research includes the literature review and content analysis of documents. The qualitative research included a questionnaire survey among guests of the gastronomic establishments and entrepreneurs. Partial least squares variant of linear discriminant analysis (PLS-LDA) and partial least squares (PLS) as an alternative to standard multivariate methods were used to show the gastronomic establishments guests' and entrepreneurs' opinions on local seasonal food and beverages. The opinions are moreover related to the economically driven interest of guests and entrepreneurs. Based on the typical random variable source, data were gathered from three Czech regions covering the scope of this study. The significant disputes between opinions on local food and beverages are directly applicable in practice, including individual items.
\end{abstract}

\section{KEYWORDS}

Collinearity, Discriminant Analysis, Economic Growth, Experience, Gastronomy Establishment, Guest, Local Beverage, Local Food, Partial Least Squares, Praha, Středočeský Region, Tourism, Ústecký Region

\section{INTRODUCTION}

Food tourism is a fundamental element of regional culture, and, as an essential part of visitors' experiences, it is a vital factor in regional development. Tourism can create jobs, attract foreign direct investment, earn foreign currency, and stimulate national, regional, and local economic growth when it is adequately supported by the state and is regulated as required.

In Organization for Economic Co-operation and Development (OECD) member countries, food and beverage services account for up to $30 \%$ of total internal tourism consumption (DuPeyras, 2016).

The World Food Travel Association (WFTA, 2020) estimates that 7.2 out of ten travelers choose their destination based on local food and beverage offer. Destination's visitors spend about $25 \%$ of their budget on food and beverages. Food travelers spend daily on average by $24 \%$ more than other travelers. Eighty percent of all travelers research food and beverages while they are visiting the 
destination. Based on the above, it can be stated that local food and beverages play an important role in destination selection and destination marketing (Seo, Yun \& Kim, 2017).

The relationship between food and tourism promotes policies that improve economic and social well-being. Food is a vital part of human culture and creativity, a significant element of intangible heritage, and an increasingly important attraction for tourists (Dupeyras, 2016). Gastronomy is one of the most important cultural expressions of human beings. The term concerns all culinary forms, including those deriving from the traditional local cuisine. Food and beverage, together with food culture practices and food heritage, are an integral component of a tourist's experience in the destination.

Gastronomy and food tourism is a factor of the regional agricultural and economic growth through the development of small and medium-sized enterprises (SMEs) and contributes to the development of the region (Királová \& Hamarneh, 2016; Mak, Lumbers, Eves, \& Chang, 2012). It is a scalable and cost-effective tool for local development that has the potential to strengthen identity, increase appreciation of the environment, and promote the regeneration of the local heritage and local economies. Tourism-related food production is, therefore, an essential mechanism for the economic development of rural areas of the regions.

Various destination management organizations consider local food as a vital tourism resource (Özdemir \& Seyitoglu, 2017) and an essential part of the destination brand (Okumus, Kock, Scantlebury \& Okumus, 2013). Food is an essential factor in promoting local products (Okumus \& Cetin, 2018; Sidali \& Hemmerling, 2014), it is one of the most shared attributes in social media (Law, Buhalis \& Cobanoglu, 2014), and if marketed on the right social media platforms (Viljoen, Kruger, \& Saayman, 2017), it can attract visitors to the destination.

In certain types of special interest tourism, food becomes a central motivation for travel (Hall \& Mitchell, 2001). Indeed, Hashimoto and Telfer (2003) note how food in tourism has developed from being a necessity to become an additional "tourist experience" that may enhance the overall evaluation of the travel experience. The maximization of economic linkages between local products and visitors is, therefore, of great importance in maximizing the contribution of tourism to the development of the regions (Hall, 2004). Food tourism can also be a tool for the economic development of those rural areas with high unemployment and low socioeconomic status in the regions.

Almeida and Garrod (2017) highlight in this context the need for destination management organizations to focus on the link between destination image and local food as marketing activities can turn experience with local food from regular consumption into a higher level of personal experiences.

The qualitative development in the behavior of visitors, manifested in a "skilled consumption" first mentioned by Scitovsky (1976) to fulfill their need for self-development or self-actualization opens the possibility for regions in the field of food tourism development. Visitors are more interested in paying for an authentic and fulfilling experience than in paying to own things. They seek an enjoyable and educational visit to a destination (Goulding, 2002) while recreational experience, heritage experience, and learning experience (Poria, Butler \& Airey, 2004) including fulfillment of emotional needs (Swarbrooke \& Horner, 2007) can be defined, among others, as the top motivations for visitation. Visitors' motivations for visiting the particular region influence their experience, level of engagement, and satisfaction (Falk \& Dierking 2000). Boswijk, Thijssen, and Peelen (2005, p. 2) define experience as a continuous process of activities "that provides meaning to the individual." Holbrook and Hirschman (1982, p. 32) point out the emotional part of the experience that contains "a steady flow of fantasies, feelings, and fun," similar to Czikszentmihalyi (1975) or Gobe, Gob and Zyman (2001).

Experience consumption (Pine \& Gilmore, 1999) is also undoubtedly associated with heritage tourism (Chen \& Chen, 2010). To be successfully marketed, the regions must provide experiences based on co-creation and collaboration (Richards, 2012) between businesses and visitors; it must encourage both parties to take an active part in the development and implementation of the experience 
(Prahalad \& Ramaswamy, 2004). If the visitors' percept the region as part of their heritage, they feel emotionally involved with it. Emotional experience, moreover, leads to positive memories, which are essential for the positive evaluation and repeat visitation. Local food can offer an emotional experience to visitors who can feel the experience and understand the uniqueness of local food of the particular region while enjoying and exploring its history and function (Graham \& Howard, 2008; Henderson, 2016). Local food at a destination allows visitors to feel a sense of place as it is linked together with geography, climate, authenticity, history, culture, and nostalgia (Bessiere, 1998; Jolliffe, 2016; Lee $\&$ Scott, 2015). This experience can be intensified by providing conditions that support experience creation to the visitors and so enable them to co-create their unique personal experience. Even if some of the visitors may avoid eating local food, they can still be curious about the local food experiences (Björk \& Kauppinen-Räisänen, 2016). The study provided by Antón, Camarero, Laguna and Buhalis (2019) following the previous study of Alderighi, Bianchi, and Lorenzini (2016), indicate that prior experience with local food is positively related to the repeated visitation of the destination.

The main objective of this study is to identify the importance of the local gastronomy for both the demand and supply sides while focusing on the offer of the local producers. The study focuses on the differences between guests' and entrepreneurs' views on the offer based on the selected variables covering the local gastronomy.

The descriptive PLS multivariate approaches were used for data processing. Such a class of methods was initially introduced in econometry (Wold, 1975; Malec, 2013), but currently, the majority of the rank of users includes distinct branches, e.g., chemical engineering and chemometrics. Although they have eligible interpretational and stability properties covering the topic of collinearity within the sets, only a limited number of applications can be found in the economy, especially in tourism. The advantages of such approaches in comparison to the standard methods create it attractive candidate tool for a specific data analysis.

\section{BACKGROUND}

Gastronomy is strongly influenced by the agricultural landscape and the environment in which are the foods produced (Sage, 2005) because of the unique character of the regions (Yeoman, Brass \& McMahon-Beattie, 2007). As a result, there are differences in regional, national, and continental levels about food when it comes to their production and consumption patterns that affect the supply and consumption of gastronomic experiences. Within Europe, there are significant differences in agricultural systems as industrial efficiency level is essential for food production in northern Europe, while the "terroir" tradition dominates southern Europe (Parrott, Wilson \& Murdoch, 2002). The French term "Cuisine de Terroir" demonstrates the importance of preparation and consumption of local foods. Shorter supply chain creates a fundamentally different type of relationship between producers and consumers (Chossat \& Gergaud, 2003). Cuisine Terroir is enriched with information about the place of production, use, recipes and thus help develop a relationship between the visitors and the region, contributing to increasing their expenditure on gastronomic products and have a multiplier effect on regional economic development.

Watts, Ilbery and Maye (2005) argue that the purchase of goods on the market carries a high level of personal interaction with alternative forms of value (economy of benefit), where there is an essential moral content (overlap) transaction beyond the exchange of products for cash.

\section{MAIN FOCUS OF THE STUDY}

Enteleca (2000) defines local food and beverages as those produced or grown in the local area or local specialties that have a local identity. Local food and beverages include fresh "farm gate" sales products, regionally branded and locally produced products, and local specialties that 
are in some way distinctive to the region, or unique. Tourism and local food have the potential for a symbiotic relationship (Hjalanger \& Richards, 2002). It is typically crucial in rural areas as the relationship between food and tourism represents a significant opportunity for product development, marketing as well as for product diversification. Specialized local traditional food and beverages create an opportunity for the development of regional rural tours, direct purchasing from the farms, and specialized restaurant menus (Bessiere, 1998). In such circumstances, tourism helps to create long-term relationships between visitors and producers as visitors often continue to purchase local food and beverages from the visited region long after they have returned to their homes (Mitchell \& Hall, 2001).

Gastronomy and food tourism can create mutual dependence on several levels, and influence the development and acceptance of the region and its cuisine by visitors. The main advantage of gastronomy and food tourism is its ability to adapt and respond to the effects of phenomena such as globalization, localization, or creolization, mainly because living culturerelated changes (Richards, 2002).

According to Yeoman and McMahon-Beattie (2016):

food tourism as a collective discourse binds farmer, producer, distributor, retailer, and consumer together, thus providing stakeholders and communities a utopian vision of the future. Through the creation of visions, political capital is created as political leaders see the opportunity to build dialogue through shared purpose, i.e., the land, food, and the tourist. These are the elements of policy and strategy which focus on the high-value tourist characterized by affluence and exclusivity. To the food tourist, food is their identity. This identity is fluid and is shaped by authenticity and hedonistic experiences.

The impact and benefits of food tourism for regions can include increased demand for foodrelated products, the building of brand loyalty, marketing intelligence for producers and suppliers, educational opportunities for visitors and residents, regional and local employment, an extension of the visitors' stay in an area, more extensive distribution of spending, and protection of intellectual property (Macleod, Robertson \& Smith, 2010; Hashimoto \& Telfer, 2003). However, according to the results of the survey conducted by UNWTO (2017), food tourism is insufficiently promoted in the regions.

The growing interest and demand from visitors for local products are very much rooted in the changing patterns of tourism, particularly the growth of "special interest" (Hall \& Mitchell, 2001) tourism. As food has been recognized as an essential part of local culture and identity (Richards, 2002), trying out local food specialties may serve to enrich the overall experience of visitors seeking to learn more about a different and authentic culture. Yeoman (2008) stated that "food is the new cultural capital of a destination as if the culture has moved out of the museum to become a living experience of consumption."

Mak et al. (2012) define five factors affecting local food consumption: culture and religion, socio-demographic factors, motivation, personality, and previous experience; some authors (Duarte, O'neill, Liu \& O'shea, 2013) consider quality and taste as significant factors affecting the local food choice.

According to Horng and Tsai (2012), a cooperating network of stakeholders in the development of gastronomy and food tourism must be designed to strengthen relations between the primary suppliers while maximizing the effects of gastronomy culture and cuisine. Creating a network of food and drink producers and offering an eating and shopping experience for visitors in authentic local promises based upon high quality and unique product that is reasonably priced is the prerequisite for satisfied visitors and as such a potential of the welfare of the regions. 


\section{ISSUES, CONTROVERSIES, PROBLEMS}

\section{Local Food and Tourism}

The food production industry is, together with agricultural production, one of the significant traditional sectors of the Czech Republic's economy. Predominant activity in the area of crop production is the cultivation of cereals and oilseeds. Besides the crops, legumes, sugar beet, potatoes, hops, fruit, vegetables, and vines are also cultivated. The country is self-sufficient regarding the production of raw cow's milk and beef. Sheep farming is a significant business activity, while quality lamb meat or goat dairy products also extend the range of goods on the market. Pork is very popular; one-half of the Czech families' expenditure on meat goes to pork. The production of poultry and eggs are decreasing in the last decade.

The Czech Ministry of Agriculture wants to ensure high quality, freshness, and health of domestic food and helps to promote Czech products by using the "KLASA" and "Regional Food" designations. The KLASA National Quality Label logo placed on the product packaging helps customers in better orientation in identifying typical Czech quality products. The quality and composition of products are assessed and controlled by the Czech Agriculture and Food Inspection Authority. The Regional Food logo on the product packaging guarantees to the consumer that the final product is based on local production and meet the most stringent European and national food quality requirements. Products awarded with the Regional Food Label show uniqueness in comparison with conventional products available on the market, whether it is a traditional recipe typical of a given region, an original production process, or the use of a specific local raw material. The Ministry also gives support to farmers' markets, farm-direct food sales, local foods, Farm Festivals, and organic farming (MA, 2013).

Food tourism is an important economic sector and social factor, which has proved its importance in maintaining the viability and sustainability of the regions. The preparation and sale of traditional and local food is an integral part of tourism. It can create an added value, especially for those visitors who are looking for new experiences, want to learn about the regional identity and culture. Local gastronomy, local products, and local food and beverages are perceived as an essential part of the local heritage. Local food can take over the role of the main attraction in the region, contribute to visitors' experience and satisfaction, and enable them to expand knowledge or cultural capital (Choe \& Kim, 2018).

The local food offer is seldom the act of one producer alone. Regional development with a focus on food tourism depends on collaboration across interests and between public and private parties (Henriksen \& Halkier, 2015). It has to be mutually beneficial and market-oriented. The close connection of the local food to the natural conditions and cultural traditions of a region, local food can be used as a place symbol that links up with a sense of authentic place.

\section{METHODOLOGY}

The analysis is based on both primary and secondary research covering a stratified sample of appropriate enterprises evaluated by using the selected experts. In this study, the gastronomic establishments in Praha (PHA), Středočeský region (STC) and Ústecký region (ULK) were sampled and further examined. These regions account for $28.3 \%$ of all gastronomic establishments in the Czech Republic that offer traditional Czech cuisine. Based on Krejcie and Morgan (1970), and including confidence $99 \%$ and margin of error 5\%, the guests' sample is estimated to 611 respondents. The predominant proportion of them was surveyed in Praha (40.84\%) and Středočeský region (40.57\%), followed by the Ústecký region. The questionnaire survey was conducted in the summer and autumn months of 2017. The study is based on a 5-point Likert scale from 1 (strongly disagree) to 5 (strongly agree). Because of both positive as well as negative significantly skewed data are exceptionally outlying in the survey data, two transformations were used by natural logarithm for the entrepreneurs and guests sets, separately. In the case of sample skewness $>2$, the simple formula was used 
$y=\log (x)+1$ while if sample skewness $<-1.7$, the variable (question) is transformed accordingly using natural logarithm on the reversed scale, but at fixed value 5 instead of 1 .

Although collinearity is a broadly discussed problem in the gastronomic input data (Vanhonacker, Lengard, Hersleth \& Verbeke, 2010; Banterle, Carraresi \& Stranieri 2010), the PLS (also called canonical covariance or intercorrelations analysis) technique is seldom used in tourism. The degree of near-collinearity within the sets is measured via determinant of sample correlation matrices herein, which values often fall below $10^{-30}$, and variance inflation factor metric. The values of relatively high within-sets relations demonstrate an unsuitable processing environment for standard multivariate methods such as multidimensional analysis of variance, discriminant, or canonical analyses. Moreover, to excellent asymptotic, interpretational, and stability properties of PLS, this range of methods testify in favor applications as significant results are often reached in case of small-sample input data compared to the number of variables (De Jong \& Kiers, 1992). From the others, a minor effect on the resulting coefficients by adding a variable to the one set should be mentioned. The coefficients of PLS originate as a minimum norm solution for the subspace of solutions having the smallest length (Malec, 2013). For this reason, in comparison to standard canonical correlation analysis, the resulting coefficients do not exhibit exceptionally high and potentially outlying values. Despite to this facts, the typical applications of PLS currently cover the disciplines distant from gastronomy and tourism, e.g., spectrometry data on green tea ranking in the work of Yamamoto, Yamaji, Fukusaki, Ohno and Fukuda (2008) and ecology to find relations between biotic indicators of surface water quality and landscape properties (Nash \& Chaloud, 2011).

The multivariate PLS variants utilize linear combinations of original variables called latent variates (LVs). In comparison to canonical correlation analysis, the PLS algorithm ranges to define a new coordinate system so that such a pair of coordinate systems is optimal in maximizing the covariance of individual variables of the first data set to LV of the second set (Wold, 1975). Malec (2016) discusses the functional relation for both PLS and canonical analysis. While in the case of PLS-LDA, the distances between LVs are to be maximized, for partial least squares, the covariance relations are in the area of interest. The results are interpreted for the significance of individual linear combinations as eigenvalues (also covering their share), coefficients of linear combinations for the relations among variables, and score as latent variate plot. In the situation of PLS-LDA for two sets, eigenvectors correspond to mean differences of unit norm variables excepting the case where data are logarithmically transformed (Malec \& Királová, 2018). In this study, the partial least squares results are not influenced by the range of possible values due to standardizing the data.

Moreover, the eigenvalues are scaled using the sample size. The other ad hoc multivariate technique, a principal component analysis (Krzanowski, 2000), was used to explain relations within the sets of data as well as to measure the shared variance. The MATLAB 7.1 software platform, with its Statistics toolbox and authors' own-written programs considering especially the various matrix decompositions, were applied.

Because PLS variants are predominantly applied in the descriptive sense, the two-dimensional statistical inference is covered in this study. The descriptive statistics and t-tests for comparison of mean differences for guests and entrepreneurs sets, as well as for revealing the significance of correlation coefficients implying economic tasks, were used. Stars standardly express significance in testing hypotheses on equality of means and the analysis of relations.

The differences between guests' and entrepreneurs' views on the offer based are examined on the selected variables covering local food and beverages. Then the task was related to individual economic interests.

The hypotheses of this study were defined as follows:

Hypothesis One: There are recognized significant disputes between guests' and entrepreneurs' opinions on local food directly applicable in practice, including individual items. 
Hypothesis Two: There are recognized significant disputes between guests' and entrepreneurs' opinions on local beverages directly applicable in practice, including individual items.

Hypothesis Three: The variety of economically driven interest in local food and beverages is proven, covering individual tasks for visitation.

\section{RESULTS}

The first eigenvalue can express the relational pattern within the individual sets of guests for input data, which for seasonal ingredients is approximately 3.296, i.e., it covers $27.46 \%$ of the variance. Black salsify, turnip, asparagus, rhubarb, and Jerusalem artichoke are positively related to this range of questions. In the case of locally produced beverages, the leading eigenvalue is 1.817 , i.e., $36.34 \%$ of the variance. Here, liquors, beers, and ciders are all the most positively related. The first issue solved covers the dispute between entrepreneurs' and guests' opinions based on a few variables on national gastronomy. The first task sounds "Which local seasonal ingredients do you choose a meal from" opposite to "Do you offer meals from the local seasonal ingredients listed below." Table 1 introduces the means (Mean) and coefficients of variation (Var) of the individual offer as well as the dispute between guests' and entrepreneurs' opinions.

Table 1. Descriptive statistics and results of PLS-LDA for individual questions

\begin{tabular}{|c|c|c|c|c|c|c|c|c|c|c|c|c|}
\hline & 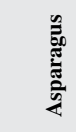 & 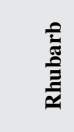 & 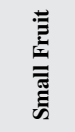 & 苛 & 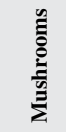 & 童 & 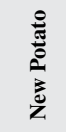 & 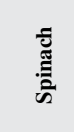 & 胥 & 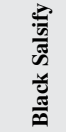 & 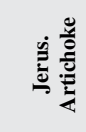 & 总 \\
\hline \multicolumn{13}{|c|}{ Descriptive statistics for guests' opinion } \\
\hline Mean & 2.559 & 2.381 & 4.119 & 3.182 & 3.299 & 2.910 & 4.077 & 3.966 & 1.728 & 1.570 & 1.809 & 3.511 \\
\hline Var & 0.540 & 0.507 & 0.240 & 0.402 & 0.445 & 0.470 & 0.260 & 0.275 & 0.593 & 0.606 & 0.656 & 0.368 \\
\hline \multicolumn{13}{|c|}{ Descriptive statistics for entrepreneurs' opinion } \\
\hline Mean & 2.727 & 2.455 & 3.941 & 3.384 & 4.001 & 2.969 & 4.131 & 3.906 & 2.138 & 1.845 & 1.872 & 3.351 \\
\hline Var & 0.426 & 0.443 & 0.236 & 0.302 & 0.245 & 0.396 & 0.214 & 0.233 & 0.511 & 0.512 & 0.538 & 0.333 \\
\hline \multicolumn{13}{|c|}{ Coefficients and t-test significance } \\
\hline LV\#1 & 0.179 & 0.079 & -0.190 & 0.215 & 0.747 & 0.063 & 0.057 & -0.064 & 0.436 & 0.293 & 0.067 & -0.171 \\
\hline $\mathrm{p}-\mathrm{val}^{\mathrm{a}}$ & $* *$ & & $* *$ & $* *$ & $* * *$ & & & & $* * *$ & $* * *$ & & $* *$ \\
\hline
\end{tabular}

aThe sample means are significantly distant with ${ }^{* * *}(p<0.001),{ }^{* *}(p<0.05)$ or ${ }^{*}(p<0.2)$

Small fruits (raspberries, bilberries, and strawberries), new potatoes, and spinach are the most demanded by the guests, opposite to the black salsify. Entrepreneurs offer new potatoes, mushrooms, small fruits, and spinach opposite to black salsify and Jerusalem artichoke. The most variable is Jerusalem artichoke, black salsify, and turnip from both sides, i.e., covering offer and demand. The eigenvalue for PLS-LDA is approximately 0.989 covering the measure of the mutual distance between two sets. The most different are mushrooms, turnip, and black salsify, which the entrepreneurs overestimate all; similarly the beetroot and asparagus opposed to small fruit and honey, which are more demanded by the guests. Here, the significance of the t-test in the processes of computations covering variances of individual input variables.

Figure 1 demonstrates that guests are not largely different, covering individual opinions. On the other hand, the entrepreneurs' set was revealed many disputes. The results of the Středočeský and Praha regions are distant; this is caused predominantly because, in the Praha region, pumpkin, turnip, 
Figure 1. Position of centroids for individual regions. Vertical lines mark location of the sets (Authors, 2020).

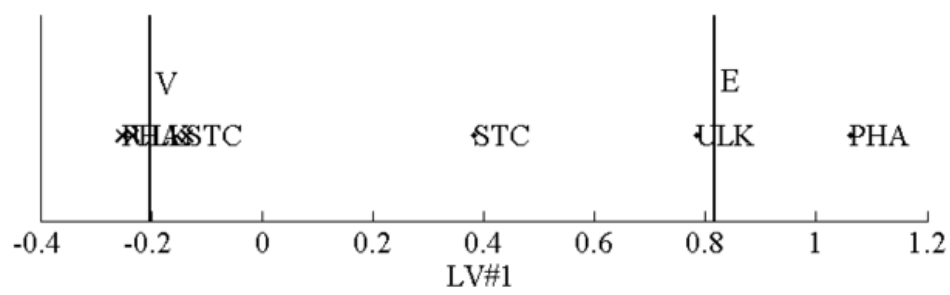

black salsify, and Jerusalem artichoke are more demanded. In the Středočeský region, asparagus, turnip, and black salsify are less demanded while simultaneously more significant interest in small fruits and new potatoes.

From Table 2 involving answers to "Do you choose drinks from local producers?" opposite to "Do you offer products from local producers?", it can be seen that guests are at the most demanding

Table 2. Descriptive statistics and results of PLS-LDA for individual questions

\begin{tabular}{|c|c|c|c|c|c|}
\hline & Wines & Beers & Ciders & Liquors & Herbal Teas \\
\hline \multicolumn{6}{|c|}{ Descriptive statistics for guests' opinion } \\
\hline Mean & 3.563 & 3.393 & 3.373 & 2.535 & 2.856 \\
\hline Var & 0.386 & 0.449 & 0.383 & 0.510 & 0.483 \\
\hline \multicolumn{6}{|c|}{ Descriptive statistics for entrepreneurs' opinion } \\
\hline Mean & 4.127 & 4.526 & 3.235 & 3.636 & 3.018 \\
\hline Var & 0.256 & 0.187 & 0.394 & 0.327 & 0.446 \\
\hline \multicolumn{6}{|c|}{ Coefficients and t-test significance } \\
\hline LV\#1 & 0.308 & 0.728 & -0.076 & 0.602 & 0.089 \\
\hline $\mathrm{p}-\mathrm{val}^{\mathrm{a}}$ & $* * *$ & $* * *$ & $*$ & $* * *$ & $* *$ \\
\hline
\end{tabular}

aThe sample means are significantly distant with ${ }^{* * *}(p<0.001),{ }^{* *}(p<0.05)$ or ${ }^{*}(p<0.2)$

wines, beers, and ciders opposite to liquors and herbal teas. Entrepreneurs are concerned about offering beers and wines opposite to herbal teas. The most variable for guests is liquors and herbal teas; for the entrepreneurs, it is herbal teas, ciders, and liquors. The dispute between guests and entrepreneurs is very significant in this case, measured by the eigenvalue 3.909. Covering PLS-LDA, the most distance between guests' and entrepreneurs' opinions are on demand for beers and liquors, which is overestimated by entrepreneurs, followed by wines also significant for the individual t-test. Guests are more demanding for ciders.

Figure 2 demonstrates that the opinions of the entrepreneurs are again more variable. In such a case, the Ústecký region is distant. Covering the complete input data, this is primarily caused by general less demanded wines, beers, and liquors in this region and more interest in herbal teas.

The second area of study examines guests' opinions on the economic interest questions supported by the local food using a partial least squares algorithm. The correlations are moreover analyzed for the significance of a simple t-test. The first task sounds: "Which local seasonal ingredients do you choose from" opposite to "If the gastronomic establishment offers seasonal food, then it will affect my behavior subsequently." In Table 3, there are introduced results of PLS. They reveal the first latent 
Figure 2. Position of centroids for individual regions. Vertical lines mark location of the sets (Authors, 2020).

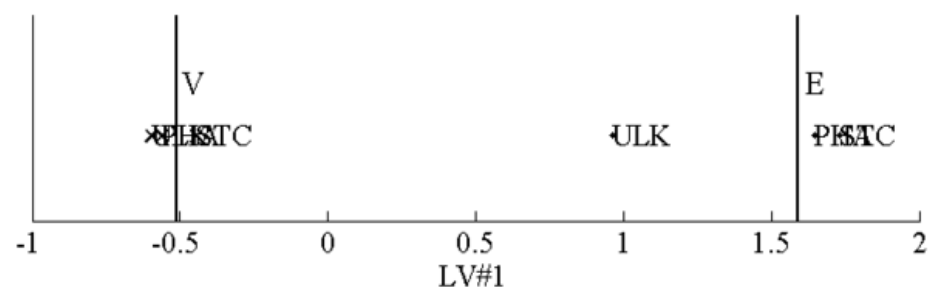

variate with the corresponding first range of coefficients covers $58.6 \%$ of the variability, and the second one for the second coefficients gathers $21.6 \%$. The offer of asparagus and pumpkin the most positively influence the guests' interest, especially visitation with friends covering the coefficients of the first latent variate. The p-values are in Table 3 expressed as a minimum of all pairs to the other set variables. The coefficients of the second latent variate reveal the positive relation between the offer of honey and spinach and visitation with friends opposite to spread the reputation of the gastronomic establishment.

\section{Table 3. First and second PLS coefficients}

\begin{tabular}{|c|c|c|c|c|c|c|c|c|c|c|c|c|}
\hline $\begin{array}{c}\text { Seasonal } \\
\text { Ingredients }\end{array}$ & Asparagus & Rhubarb & $\begin{array}{l}\text { Small } \\
\text { Fruit }\end{array}$ & Beetroot & Mushrooms & Pumpkin & $\begin{array}{c}\text { New } \\
\text { Potatoes }\end{array}$ & Spinach & Turnip & $\begin{array}{r}\text { Black } \\
\text { Salsify }\end{array}$ & $\begin{array}{l}\text { Jerusalem } \\
\text { Artichoke }\end{array}$ & Honey \\
\hline LV\#1 & 0.558 & 0.229 & -0.274 & -0.118 & 0.171 & 0.486 & -0.288 & -0.227 & -0.218 & 0.034 & 0.309 & -0.061 \\
\hline LV\#2 & 0.384 & 0.322 & 0.110 & 0.031 & -0.154 & -0.038 & 0.321 & 0.420 & 0.234 & 0.325 & 0.156 & 0.496 \\
\hline $\mathrm{p}$-val ${ }^{\mathrm{a}}$ & $* * *$ & * & & & & *** & $*$ & & & & * & \\
\hline $\begin{array}{c}\text { Guests } \\
\text { Interest }\end{array}$ & $\begin{array}{c}\text { Come } \\
\text { More } \\
\text { Times }\end{array}$ & $\begin{array}{l}\text { Willingly } \\
\text { Pay More }\end{array}$ & $\begin{array}{l}\text { Come } \\
\text { With } \\
\text { Friends }\end{array}$ & $\begin{array}{l}\text { Spread the } \\
\text { Reputation }\end{array}$ & & & & & & & & \\
\hline LV\#1 & 0.503 & 0.373 & 0.582 & 0.519 & & & & & & & & \\
\hline LV\#2 & -0.133 & -0.166 & 0.765 & -0.609 & & & & & & & & \\
\hline$p-v_{a}{ }^{\mathrm{a}}$ & $* *$ & & ***** & *** & & & & & & & & \\
\hline
\end{tabular}

${ }^{\text {aAt least one correlation is significant with }}{ }^{* * *}(p<0.01),{ }^{* *}(p<0.05)$ or ${ }^{*}(p<0.1)$

The ratio of significant pairs of correlations at 0.05 is relatively low in this case, covering $10.4 \%$. Here, Středočeský region relational pattern is relatively different from others covering both economic interest and various seasonal ingredients on the first latent variate (see Figure 3). The difference is caused due to the opposite relation of the small fruits, beetroot, and honey to all economic interests of the guests, especially willingly pay more and spread the reputation. Covering the second latent

Figure 3. PLS score plot (Authors, 2020)

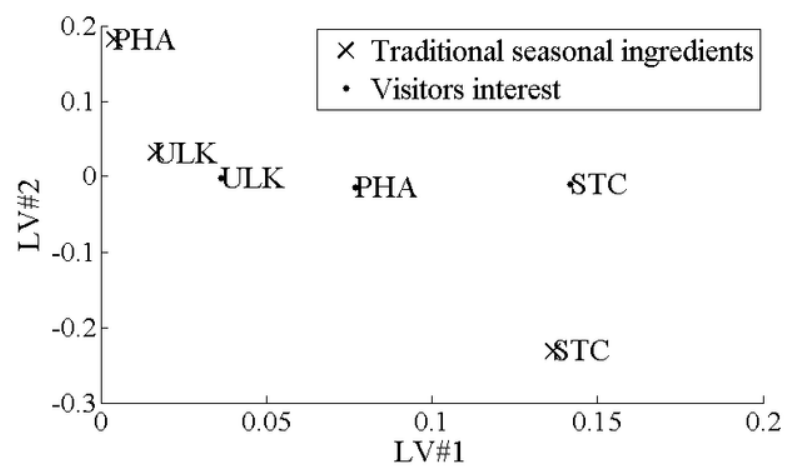


variate, the result for Středočeský region shows negative relations between pumpkin and Jerusalem artichoke and willingness to pay more and positive relation to visitation with friends and spreading the reputation. Praha region covering the second latent variate is more favorable to all seasonal examined ingredients.

The second area of questions encompassing relations of input variables is for "Do you choose drinks from local producers" and "If a gastronomic establishment offers beverages from local producers, then it will affect my behavior as follows." For the coefficients of the first latent variate, the significance is $76.4 \%$, and for the second, the share on variance gathers $13.7 \%$ (Table 4). Wines and herbal teas' offer increase the guests' interests, especially in spreading the reputation and visiting

Table 4. First and second PLS coefficients

\begin{tabular}{|c|c|c|c|c|c|}
\hline $\begin{array}{l}\text { Regionally } \\
\text { Produced } \\
\text { Beverages }\end{array}$ & Wines & Beers & Ciders & Liquors & Herbal Teas \\
\hline LV\#1 & 0.714 & 0.055 & 0.276 & 0.290 & 0.572 \\
\hline LV\#2 & 0.357 & 0.132 & -0.786 & 0.397 & -0.281 \\
\hline $\mathrm{p}-\mathrm{val}^{\mathrm{a}}$ & $* * *$ & & $*$ & & $* * *$ \\
\hline Guests' Interest & $\begin{array}{c}\text { Come More } \\
\text { Times }\end{array}$ & $\begin{array}{c}\text { Willingly Pay } \\
\text { More }\end{array}$ & $\begin{array}{l}\text { Come With } \\
\text { Friends }\end{array}$ & $\begin{array}{l}\text { Spread the } \\
\text { Reputation }\end{array}$ & \\
\hline LV\#1 & 0.512 & 0.430 & 0.477 & 0.571 & \\
\hline LV\#2 & 0.680 & 0.325 & -0.399 & -0.522 & \\
\hline $\mathrm{p}-\mathrm{val}^{\mathrm{a}}$ & $* * *$ & $* *$ & $* *$ & $* * *$ & \\
\hline
\end{tabular}

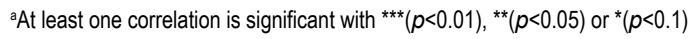

the gastronomic establishment more times. The p-values for pair of questions correspond primarily to the outputs of PLS covering its coefficients. The second latent variate reveals that ciders are negatively related to visiting more times the gastronomic establishment opposite to spreading the reputation.

The relations are relatively significant in this case, also measured by the proportion of correlations significant at 0.05 , which is $79.2 \%$. Figure 4 introduces the score plot. The first latent variate describes the most distant Ústecký region due to various covariance patterns encompassing wines and herbal teas, which are more pronounced in connection to economic parameters, mainly to visitation with friends and visiting more times. In the case of the second latent variate, Středočeský region is predominantly distant due to relations of the ciders offer covering lower economic interests in gastronomic trends.

Figure 4. PLS score plot (Authors, 2020)

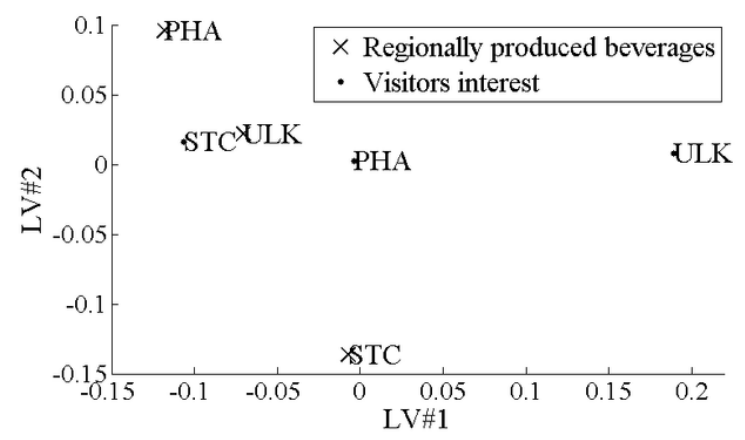




\section{CONCLUSION}

Local food and beverages enhance the appeal of a region. Visitors who are seeking for nature and local culture are also interested in sampling local food products and tasting authentic food and drinks. More attention should be paid to the local food and beverages as they can add value to a region as a whole and contribute to its development. Food tourism is not purely an income-generating activity but also a cultural enhancement activity contributing to the tourism experience. It, therefore, needs to be considered as an essential component of the marketing activities of a region.

The results of this empirical study demonstrate that both PLS-LDA and PLS methods lead to direct answers to the hypotheses set, simultaneously being less sensitive to limitations of standard multivariate approaches. They prove to be a valuable statistical analysis tool in tourism research. These methods can be applied broadly to tourism issues covering gastronomic tasks extending the previous discussion specifically in the context of the territories studied. The main results of this study can be shortly summarized as follows.

Hypothesis One: There are recognized significant disputes between guests' and entrepreneurs' opinions on local seasonal ingredients, although the beverages' task is more separated. The most demanded local foodstuffs by guests are small fruits, new potatoes, and spinach opposite to black salsify. The most different among guests and representatives of catering establishments are mushrooms, turnip and black salsify for the entrepreneurs overestimated all, which offers. To a lesser extent, this is also the case for beetroot and asparagus opposite to small fruits and honey. Středočeský Region and Praha region show different results in the set of entrepreneurs. Praha's entrepreneurs favor pumpkin, turnip, black salsify, and Jerusalem artichoke. At the same time, Středočeský region is demanding less asparagus, turnip, and black salsify with a simultaneous higher interest in small fruits and new potatoes.

Hypothesis Two: There are recognized significant disputes between guests' and entrepreneurs' opinions on local beverages. Guests' interest in drinks covering local producers' offer is focusing on wines, beers, and ciders opposite to liquors and herbal teas. The most overestimated offers by entrepreneurs are beers and liquors, followed by wines. The results from the Ústecký region are different in entrepreneurs set caused by less demand for wines, beers, and liquors in the region and higher interest in herbal teas.

Hypothesis Three: The variety of economically driven interest in local food and beverages is proven. It was revealed that asparagus and pumpkin as seasonal ingredients most positively influence the guests' interest, especially enhance the visitation of gastronomic establishments with friends. Středočeský region behaves differently as herein, small fruits, beetroot, and honey are opposite to all the economic tasks studied. The offer of the local wines and herbal teas increases the guests' interest and positively affects the spreading of the goodwill and the reputation of the gastronomic establishments what is reflected in repeated visits. Ústecký region shows different results due to strong positive relation to similar beverages and including more economic parameters, especially by a visit with friends and repeat visitation.

\section{ACKNOWLEDGMENT}

This research received no specific grant from any funding agency in the public, commercial, or notfor-profit sectors.

\section{FUNDING AGENCY}

Open Access Funding for this article has been provided by IGI Global. 


\section{REFERENCES}

Alderighi, M., Bianchi, C., \& Lorenzini, E. (2016). The impact of local food specialities on the decision to (re)visit a tourist destination: Market-expanding or business-stealing? Tourism Management, 57(December), 323-333. doi:10.1016/j.tourman.2016.06.016

Almeida, A., \& Garrod, B. (2017). Experiences with local food in a mature tourist destination: The importance of consumers' motivations. Journal of Gastronomy and Tourism, 2(3), 173-187. doi:10.3727/21692971 $7 X 14870140201116$

Antón, C., Camarero, C., Laguna, M., \& Buhalis, D. (2019). Impacts of authenticity, degree of adaptation and cultural contrast on travellers' memorable gastronomy experiences. Journal of Hospitality Marketing \& Management, 28(7), 1-23. doi:10.1080/19368623.2019.1564106

Banterle, A., Carraresi, L., \& Stranieri, S. (2010). Small Business Marketing Capability in the Food Sector: The Cases of Belgium, Hungary and Italy. International Journal on Food System Dynamics, 1(2), 94-102.

Besiére, J. (1998). Local development and heritage: Traditional food and cuisine as tourist attractions in rural areas. Sociologia Ruralis, 28(1), 21-34. doi:10.1111/1467-9523.00061

Björk, P., \& Kauppinen-Räisänen, H. (2016). Local food: A source for destination attraction. International Journal of Contemporary Hospitality Management, 28(1), 177-194. doi:10.1108/IJCHM-05-2014-0214

Boswijk, A., Thijssen, T., \& Peelen, E. (2005). The Experience Economy, a New Perspective. Pearson Education Benelux.

Cetin, G., \& Bilgihan, A. (2016). Components of cultural tourists' experiences in destinations. Current Issues in Tourism, 19(2), 137-154. doi:10.1080/13683500.2014.994595

Chen, C., \& Chen, F. (2010). Experience Quality, Perceived Value, Satisfaction and Behavioral Intentions for Heritage Tourists. Tourism Management, 31(1), 29-35. doi:10.1016/j.tourman.2009.02.008

Choe, J. Y., \& Kim, S. (2018, November). Effects of tourists' local food consumption value on attitude, food destination image, and behavioral intention. International Journal of Hospitality Management, 71, 1-10. doi:10.1016/j.ijhm.2017.11.007

Chossat, V., \& Gergaud, O. (2003). Expert Opinion and Gastronomy: The Recipe for Success. Journal of Cultural Economics, 27(2), 127-141. doi:10.1023/A:1023432502059

Czikszentmihalyi, M. (1975). Beyond Boredom and Anxiety: The Experience of Play in Work and Games. Jossey-Bass Publishers.

De Jong, S. \& Kiers, H. A. L. (1992). Principal covariates regression. Chemometrics and Intelligent Laboratory Systems - Part I: Theory, 14(1-3), 155-164.

Duarte, A. A., O'neill, M., Liu, Z., \& O'shea, M. (2013). Factors driving consumer restaurant choice: An exploratory study from the Southeastern United States. Journal of Hospitality Marketing \& Management, 22(5), 547-567. doi:10.1080/19368623.2012.671562

DuPeyras, A. (2016). Growth of Sharing Economy in Tourism: Developing a Balanced Policy Response. OECD.

Enteleca. (2000). Tourist's attitudes towards regional and local food. Enteleca Research and Consultancy. Retrieved from: http://www.tourisminsights.info/ONLINEPUB/FARMING\%20AND\%20FOOD/FOOD\%20 PDFS/tourist\%20attitutes\%20to\%20local\%20foods.pdf

Falk, J. H., \& Dierking, L. D. (2000). Learning from Museums: Visitor Experiences and the Making of Meaning. Lanham, MD: Rowman \& Littlefield.

Gobe, M., Gob, M., \& Zyman, S. (2001). Emotional Branding: The New Paradigm for Connecting Brands to People. Allworth Press.

Goulding, C. (2002). The Commodification of the Past, Postmodern Pastiche, and the Search for Authentic Experiences at Contemporary Heritage Attractions. European Journal of Marketing, 34(7), 835-853. doi:10.1108/03090560010331298 
Graham, B., \& Howard, P. (2008). Heritage and Identity. The Routledge Research Companion to Heritage and Identity (Ashgate Research Companion). Routledge.

Hall, C. M. (2004). Small firms and wine and food tourism in New Zealand: Issues of collaboration, clusters and lifestyles. In R. Thomas (Ed.), Small firms in tourism: International perspectives (pp. 167-181). Elsevier. doi:10.1016/B978-0-08-044132-0.50014-9

Hall, C. M., \& Mitchell, R. (2001). Wine and food tourism. In Special interest tourism (pp. 307 - 329). Brisbane: John Wiley \& Sons.

Hashimoto, A., \& Telfer, D. J. (2003). Food tourism in the Niagara region: The development of a ,nouvelle cuisine. In C. M. Hall, E. Sharples, R. Mitchell, B. Cambourne, \& N. Macionis (Eds.), Food tourism around the world: Development, management and markets (pp. 178-191). Butterworth-Heinemann.

Henderson, J. C. (2016). Local and traditional or global and modern? Food and tourism in Singapore. Journal of Gastronomy and Tourism, 2(1), 55-68. doi:10.3727/216929716X14546365943494

Henriksen, P. F., \& Halkier, H. (2015). Feeding countryside tourists: Exploring collaborative actor strategies in rural Denmark. In K. Dashper (Ed.), Rural tourism - An international perspective (pp. 250-266). Cambridge Scholars.

Hjalager, A., \& Richards, G. (Eds.). (2002). Tourism and Gastronomy. Routledge.

Holbrook, M. B., \& Hirschmann, E. C. (1982). The Experiental Aspects of Consumption: Consumer Fantasies, Feelings, and Fun. The Journal of Consumer Research, 9(2), 132-140. doi:10.1086/208906

Horng, J.-S., \& Tsai, C.-T. S. (2012). Culinary tourism strategic development: An Asia-Pacific perspective. International Journal of Tourism Research, 14(1), 40-55. doi:10.1002/jtr.834

Jolliffe, L. (2016). Marketing culinary tourism experiences. In M. Sotiriadis \& D. Gursoy (Eds.), The Handbook of Managing and Marketing Tourism Experiences (pp. 363-378). Emerald Group Publishing Limited. doi:10.1108/978-1-78635-290-320161014

Királ'ová, A., \& Hamarneh, I. (2016). Embracing tourism SMEs development through food tourism in the Czech regions. In 19th International Colloquium on Regional Sciences. Conference Proceedings (pp.1064-1073). Brno: Masaryk University.

Krejcie, R. V., \& Morgan, D. W. (1970). Determining sample size for research activities. Educational and Psychological Measurement, 30(3), 607-610. doi:10.1177/001316447003000308

Krzanowski, W. J. (2000). Principles of multivariate analysis: A user's perspective. University Press.

Law, R., Buhalis, D., \& Cobanoglu, C. (2014). Progress on information and communication technologies in hospitality and tourism. International Journal of Contemporary Hospitality Management, 26(5), 727-750. doi:10.1108/IJCHM-08-2013-0367

Lee, K. H., \& Scott, N. (2015). Food tourism reviewed using the paradigm funnel approach. Journal of Culinary Science \& Technology, 13(2), 95-115. doi:10.1080/15428052.2014.952480

Lunchaprasith, T. (2017). Gastronomic experience as a community development driver: The study of Amphawa Floating Market as community-based culinary tourism destination. Asian Journal of Tourism Research, 2(2), 84-116. doi:10.12982/AJTR.2017.0011

MA CR. (2013). Supporting our rural traditions \& development. Ministry of Agriculture of the Czech Republic.

Mak, A. H. N., Lumbers, M., Eves, A., \& Chang, R. C. Y. (2012). Factors influencing tourist food consumption. International Journal of Hospitality Management, 31(4), 928-936. doi:10.1016/j.ijhm.2011.10.012

Malec, L. (2013). On the multivariate processing of rank-deficient tourism data. European Journal of Tourism. Hospitality and Recreation, 4(3), 181-203.

Malec, L. (2016). Some remarks on the functional relation between canonical correlation analysis and partial least squares. Journal of Statistical Computation and Simulation, 86(12), 2379-2391. doi:10.1080/00949655 .2015 .1110821 
Malec, L., \& Királová, A. (2018). Evaluating competencies of graduates in tourism as a prerequisite for future employability. Prague Economic Papers, 27(2), 196-214. doi:10.18267/j.pep.651

Mitchell, R., \& Hall, C. M. (2001). Lifestyle behaviours of New Zealand winery visitors: Wine club activities, wine cellars and place of purchase. International Journal of Wine Marketing, 13(3), 82-94. doi:10.1108/eb008729

Nash, M. S. \& Chaloud, D. J. (2011). Partial least square analyses of landscape and surface water biota associations in the Savannah River Basin. International Scholarly Research Network, Ecology, 2011. (Article ID 571749)

Okumus, B., \& Cetin, G. (2018). Marketing Istanbul as a culinary destination. Journal of Destination Marketing \& Management, 9(September), 340-346. doi:10.1016/j.jdmm.2018.03.008

Okumus, F., Kock, G., Scantlebury, M. M., \& Okumus, B. (2013). Using local cuisines when promoting small Caribbean island destinations. Journal of Travel \& Tourism Marketing, 30(4), 410-429. doi:10.1080/1054840 8.2013.784161

Özdemir, B., \& Seyitoglu, F. (2017). A conceptual study of gastronomical quests of tourist: Authenticity or safety and comfort? Tourism Management Perspectives, 23(1), 1-7. doi:10.1016/j.tmp.2017.03.010

Parrott, N., Wilson, N., \& Murdoch, J. (2002). Spatializing Quality: Regional Protection and the Alternative Geography of Food. European Urban and Regional Studies, 9(3), 241-261. doi:10.1177/096977640200900304

Pine, B. J., \& Gilmore, J. H. (1999). The Experience Economy: Work is Theatre \& Every Business a Stage. Harvard Business School Press.

Poria, Y., Butler, R., \& Airey, D. (2004). Links between Tourists, Heritage, and Reasons for Visiting Heritage Sites. Journal of Travel Research, 43(1), 19-28. doi:10.1177/0047287504265508

Prahalad, C. K., \& Ramaswamy, V. (2004). Co-creating Unique Value with Customers. Strategy and Leadership, 32(3), 4-9. doi:10.1108/10878570410699249

Richards, G. (2002). Gastronomy: An essential ingredient in tourism production and consumption? In A. M. Hjalager \& G. Richards (Eds.), Tourism and gastronomy (pp. 3-24). Routledge.

Richards, G. (2012). An Overview of Food and Tourism Trends and Policies. In OECD Food and the Tourism Experience: The OECD-Korea Workshop. OECD Studies on Tourism.

Sage, C. (2005, June). Food for thought. The Irish Times, 28.

Scitovsky, T. (1976). The Joyless Economy. An Inquiry into Human Satisfaction and Consumer Dissatisfaction. Oxford University Press.

Seo, S., Yun, N., \& Kim, O. Y. (2017). Destination food image and intention to eat destination foods: A view from Korea. Current Issues in Tourism, 20(2), 135-156. doi:10.1080/13683500.2014.934210

Sidali, L. K., \& Hemmerling, S. (2014). Developing an authenticity model of traditional food specialties: Does the self-concept of consumers matter? British Food Journal, 116(11), 1692-1709. doi:10.1108/BFJ-02-2014-0056

Smith, M., MacLeod, N., \& Hart Robertson, M. (2010). Key Concepts in Tourist Studies. Key Concepts series. SAGE.

Swarbrooke, J., \& Horner, S. (2007). Consumer Behaviour in Tourism. Butterworth-Heinemann.

UNWTO. (2017). Second Global Report on Gastronomy Tourism. UNWTO.

Vanhonacker, F., Lengard, V., Hersleth, M., \& Verbeke, W. (2010). Profiling European traditional food consumers. British Food Journal, 112(8), 871-886. doi:10.1108/00070701011067479

Viljoen, A., Kruger, M., \& Saayman, M. (2017). The 3-S typology of South African culinary festival visitors. International Journal of Contemporary Hospitality Management, 29(6), 1560-1579. doi:10.1108/ IJCHM-09-2015-0464

Watts, D. C. H., Ilbery, B., \& Maye, D. (2005). Making reconnections in agro-food geography: Alternative systems of food provision. Progress in Human Geography, 29(1), 22-40. doi:10.1191/0309132505ph526oa 
WFTA. (2020). The culinary traveler. World Food Travel Association. Retrieved from: https://worldfoodtravel. org/what-is-food-tourism-definition-food-tourism/

Wold, H. (1975). Path models with latent variables: The NIPALS approach. In H. M. Blalock, A. Aganbegian, F. M. Borodkin, R. Boudon, \& V. Capecchi (Eds.), Quantitative Sociology: International Perspectives on Mathematical and Statistical Model Building (pp. 307-357). Academic Press. doi:10.1016/B978-0-12-103950-9.50017-4

Yamamoto, H., Yamaji, H., Fukusaki, E., Ohno, H., \& Fukuda, H. (2008). Canonical correlation analysis for multivariate regression and its application to metabolic fingerprinting. Biochemical Engineering Journal, 40(2), 199-204. doi:10.1016/j.bej.2007.12.009

Yeoman, I. (2008). Why food tourism is becoming more important? Hospitalitynet, Industry News. Retrieved from: https://www.hospitalitynet.org/news/4037197.html

Yeoman, I., Brass, D., \& McMahon-Beattie, U. (2007). Current issue in tourism: The authentic tourist. Tourism Management, 28(4), 1128-1138. doi:10.1016/j.tourman.2006.09.012

Yeoman, I., \& McMahon-Beattie, U. (2016). The future of food tourism. Journal of Tourism Futures, 2(1), 95-98. doi:10.1108/JTF-12-2015-0051

Zhang, T., Chen, J., \& Hu, B. (2019). Authenticity, Quality, and Loyalty: Local Food and Sustainable Tourism Experience. Sustainability, 11(12), 3437. doi:10.3390/su11123437

Alžbeta Királová has graduated in tourism at the University of Economics in Slovakia. After completing her Ph.D. studies, she holds the position of the head of the Department of Tourism and Hospitality at Matej Bel University, Slovakia. Later on, in her career development, she worked at top management positions in marketing, continued by the position of Vice-Rector at the Institute of Hospitality Management, and at the University College of Business in Prague. She was giving lectures at the University of Economics, and at the University of New York in Prague, the University of South Carolina in Columbia, and at the Georgia State University in Atlanta, USA. At the moment, she holds the position of Vice-Rector at the College of Regional Development and Banking Institute - AMBIS, a. s. in Prague, Czech Republic. Dr. Királ'ová completed various international internships and was given papers at international conferences. In her research, she focuses on destination marketing. She is the founder of the Journal of Tourism and Services.

Lukáš Malec $(P h D)$ has received MSc. and Ph.D. from the Institute of Chemical Technology in Prague. Currently, he is the head of the Department of Information Technologies and Analytical Methods at University College of Business. His research interests include air pollution modeling, general statistics, multivariate analysis covering smooth matrix decompositions, and economic and tourism applications. Dr. Malec solves several projects and grants and is a reviewer of economic journals. During his professional career, he has undergone plenty of research stays. 